\title{
Making the matrix matter: challenges in Australian grazing landscapes
}

\author{
JOERN FISCHER ${ }^{1, *}$, IOAN FAZEY $^{1}$, ROBYN BRIESE ${ }^{2}$ \\ and DAVID B. LINDENMAYER ${ }^{1}$ \\ ${ }^{1}$ Centre for Resource and Environmental Studies, The Australian National University, Canberra, ACT \\ 0200, Australia; ${ }^{2}$ Phillips Fox Lawyers, Phillips Fox Building, 54 Marcus Clarke Street, Canberra, ACT \\ 2601, Australia; *Author for correspondence (e-mail: joern@cres.anu.edu.au; fax: +61-2-6125-0757)
}

Received 9 April 2003; accepted in revised form 11 November 2003

Key words: Australia, Biodiversity conservation, Birds, Matrix management, Reptiles

\begin{abstract}
Many ecological theories are based on the concept of patches. Patches are a useful starting point for conservation efforts, but a focus on patches alone will not always achieve desired conservation outcomes. Conservation strategies in the grazing landscapes of southeastern Australia suggest that large patches of trees are widely regarded as 'habitat' while other forms of habitat are largely ignored. We provide data on birds and reptiles from the Nanangroe grazing landscape that illustrate the potential habitat value of areas located between large patches of trees - that is, the matrix. Despite evidence on its potential value, present conservation strategies rarely consider the matrix. Possible reasons for this bias relate to the economics of farming and the history of land use, the current environmental law framework, and also the reluctance of ecologists to study the matrix. More scientific evidence on the role of the matrix will be crucial if conservation strategies are to consider not only patches, but entire landscapes. However, for science to be relevant to land management, there is a need for new research approaches. First, an increased consideration of environmental policy and law will increase the likelihood of scientific findings being adopted by policy makers. Second, at an applied level, more practical on-ground research into farming practices and clearer communication are necessary to achieve more sustainable matrix management in Australian grazing landscapes.
\end{abstract}

\section{Introduction}

The concept of 'patches' is central to many ecological theories (Stephens and Krebs 1986; Wiens et al. 1993; Antrop 2001) and conservation strategies (e.g., Diamond 1975). At the global scale, networks of large patches that are reserved from production (e.g., national parks) are widely regarded as an important backbone of successful biodiversity conservation (Diamond 1975; Higgs and Usher 1980; Kitchener 1982; Margules and Pressey 2000). Similarly, at the landscape scale, patches of remnant vegetation are considered important for conservation efforts in modified landscapes (Saunders et al. 1987). However, an exclusive focus on patches of trees may lead to suboptimal conservation outcomes in some modified landscapes. This is because areas outside patches - that is, the 'matrix' - often play an important complementary role for a range of organisms (Daily 2001; Luck and Daily 2003).

In this paper, we consider a case study from a grazing landscape in south-eastern Australia, and highlight key ecological functions of the matrix for birds and 
reptiles. In addition, we discuss potential barriers to improved matrix management and how they may be overcome. We conclude that for conservation biology to make a useful contribution to improved matrix management, more interdisciplinary investigations are needed. For example, an increased understanding of environmental law will help influence the environmental policy framework, and detailed on-ground research examining the effect of farming practices on matrix condition will help identify more sustainable management regimes. Finally, the clear communication of ecological complexity will be important to highlight that habitat is more than large patches of trees, and that a 'soft matrix' can provide habitat for a range of organisms.

\section{Reptiles and birds in the Nanangroe grazing landscape}

The Nanangroe area is located in southern New South Wales, southeastern Australia $\left(34^{\circ} 58^{\prime} \mathrm{S}, 148^{\circ} 29^{\prime} \mathrm{E}\right)$. It has a temperate climate with relatively hot summers (daily maxima often above $30^{\circ} \mathrm{C}$ ), and cool winters with occasional night-time frost events. Prior to European settlement, much of the Nanangroe area was covered by native eucalypt woodlands, particularly those dominated by Yellow Box/Blakely's Red Gum (Eucalyptus melliodora/E. blakelyi) and White Box (E. albens; Yates and Hobbs 1997). Today, native tree cover is reduced to approximately $15 \%$, and most cover takes the form of relatively small woodland remnants (generally less than $15 \mathrm{ha}$ ), or semi-isolated trees in the pastures (termed 'paddock trees'). Isolation distances between habitat remnants or semi-isolated trees range from dozens to hundreds of metres. The area is best described as variegated (sensu McIntyre and Barrett 1992; McIntyre and Hobbs 1999). That is, the matrix between substantial woodland remnants is characterised by gradual changes in vegetation cover and scattered paddock trees rather than sharp boundaries.

The Nanangroe grazing area incorporates several private grazing properties, covering a total area of approximately $200 \mathrm{~km}^{2}$. Several bird and reptile surveys were conducted over the last 4 years (Tables 1 and 2). Birds were surveyed using point count techniques (Table 1). Reptiles were surveyed using pitfall trapping and active searching at 144 ten by ten metre plots, and artificial coverboards (sensu Grant et al. 1991) at 125 additional locations (Lindenmayer et al. 2001; Fischer et al., unpublished data) covering a range of environments. Each fauna survey was accompanied by surveys of habitat structure, which included the quantification of fallen timber, rocks and various vegetation attributes.

\section{Ecological functions of the matrix}

Lindenmayer and Franklin (2002) argued there were two different, but related definitions of what constituted the 'matrix': (1) the area outside reserves, or (2) the area between patches of remnant vegetation. The Nanangroe landscape is a 


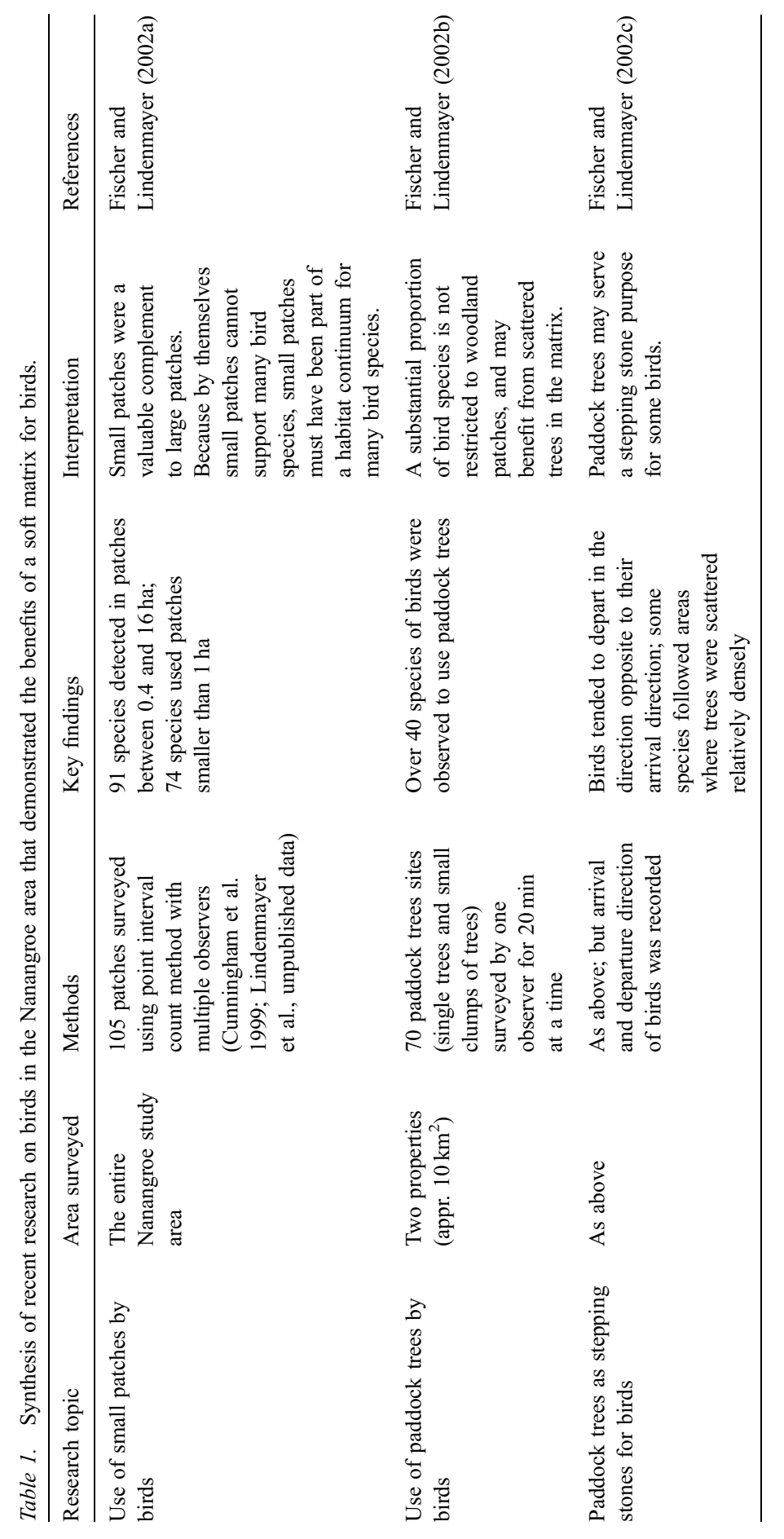




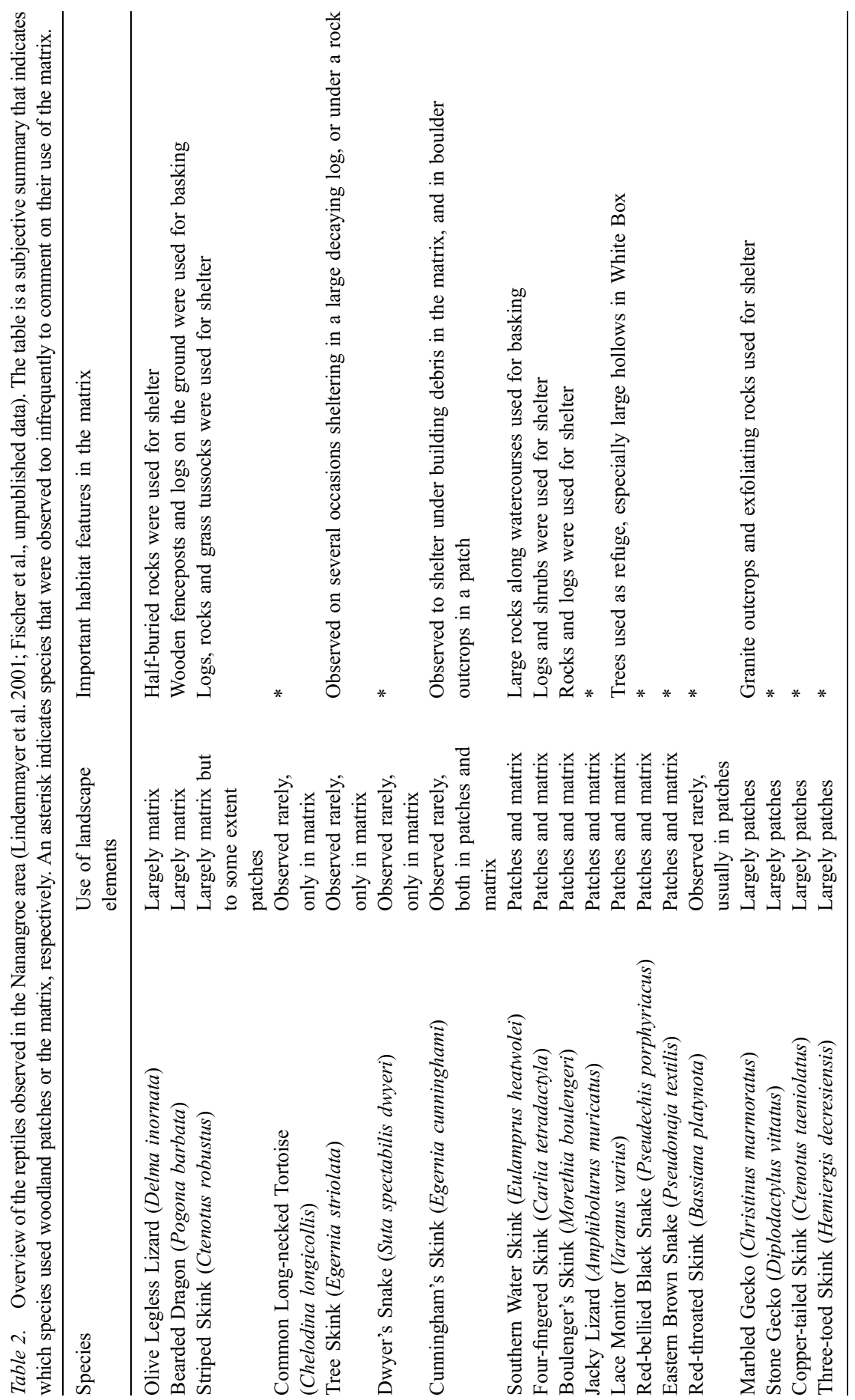


production landscape, and as such, the entire study area is part of the matrix according to the first definition. For the remainder of this paper, we use the second definition of the matrix - that is, we are concerned with the areas between patches of native woodland. The delineation of patch boundaries in a variegated landscape is by necessity somewhat subjective. In Nanangroe, we used aerial photographs to delineate patch boundaries, and patch sizes thus obtained ranged between 0.4 and 16 ha.

To describe the nature of the matrix, the terms 'soft' and 'heterogeneous' are used in this paper to reflect relatively high complexity of vegetation structure, and ground cover (see Franklin 1993). While there was substantial variability of these attributes throughout the Nanangroe landscape (Fischer et al., unpublished data), the overall heterogeneity of the Nanangroe landscape was high compared to similar farming landscapes in the region (e.g., relatively high levels of fallen timber, rock cover, some native shrubs).

\section{A soft matrix can provide habitat}

The matrix in the Nanangroe landscape was characterised by a relatively high amount of heterogeneity expressed through the presence of scattered trees, fallen timber, rocky patches and areas with relatively tall grass (mostly introduced species). A key function of the matrix was to provide habitat for several species of birds and reptiles. For example, more than 90 species of birds were observed in the Nanangroe study area (Table 1; Lindenmayer et al., unpublished data), although only approximately $15 \%$ of the original woodland cover remained. Most of these species were not restricted to large woodland patches, and even small patches $(<1 \mathrm{ha})$ contributed highly to cumulative species richness across the entire study area (Table 1). In addition, during a survey of scattered trees in the matrix, we found that almost every second species of bird in the study area used the matrix (Table 1). Thus, the variegated nature of the landscape and its relatively soft matrix contributed substantially to local bird diversity. This was because many species of birds used very small woodland patches and scattered trees in the matrix as part of a larger habitat mosaic (Table 1).

The matrix also was used by nearly three quarters of the reptile species recorded in the Nanangroe area, and features such as rocks, logs and other tree-related habitat attributes were important refuge sites for many species (Table 2). Other studies in a range of different ecosystems have also shown that the matrix should not be neglected as potential habitat (reviewed by Lindenmayer and Franklin 2002). In northern Victoria, Lumsden et al. (2002) demonstrated that most bat species utilised the matrix for foraging, although some species were reliant on larger forest patches for roosting sites. The matrix may be equally important to complement existing patches in very different environments. For example, Fernández-Juricic (2000) found that wooded streets in the city of Madrid (Spain) contributed substantially to urban bird diversity. Similarly, selectively logged forests in northern Borneo have the potential to support a diverse array of butterfly species, provided 
habitat heterogeneity is maintained (Hamer et al. 2003). The ability of species to persist in the matrix can be a key factor in determining their extinction proneness (Laurance 1991; Gascon et al. 1999). Hence, the maintenance of a wide range of different habitat features throughout the matrix can be important for the maintenance of regional biodiversity.

While some initial habitat relationships have been established in Australian grazing landscapes (e.g., Tables 1 and 2), there is ample scope for more detailed research. A possible guiding framework may be 'countryside biogeography', which recognises the need to study and manage biodiversity in human-modified landscapes (e.g., Daily 2001; Luck and Daily 2003). A wide range of issues can be addressed using this framework. For example, a series of studies in the Las Cruces farming landscape in southern Costa Rica provides clues as to what sorts of research questions may be worth asking in Australian grazing landscapes (Daily 1999, 2001). Examples include an explicit assessment of the effect of landscape context on biodiversity (Ricketts et al. 2001; Horner-Devine et al. 2003; Luck and Daily 2003), and an appraisal of how the matrix is used by various species. For example, it can be important to know if the matrix can provide breeding habitat for native species, or if it is mainly used for foraging (e.g., in the case of birds; see Hughes et al. 2002).

\section{A soft matrix can enhance connectivity}

An important consideration for regional conservation is to maintain habitat connectivity to facilitate movement between areas of habitat and thus maintain viable populations (Saunders and de Rebeira 1991; Taylor et al. 1993; Ferreras 2001). Traditionally, connectivity in modified landscapes has been thought to be best achieved through the establishment of wildlife corridors that link 'habitat patches' (reviewed by Lindenmayer 1994, 1998; Beier and Noss 1998; Bennett 1998). However, wildlife corridors will have certain physical attributes and link certain habitat types at one or few spatial scales that may suit some, but not all species. Given these and other limitations of corridors (see Simberloff et al. 1992), it is important to consider the potential of a soft matrix to increase connectivity for species across a range of scales and habitat types.

At Nanangroe, we found some indication that scattered trees in the matrix were particularly important landscape elements that contributed to landscape connectivity for various species of birds. For example, some bird species were more likely to travel through the landscape in directions where trees were scattered relatively densely (Table 1). In addition, after landing in a semi-isolated tree in the matrix, many birds returned to their point of origin, or departed in the direction opposite to their arrival direction, which indicated the potential role of scattered trees as stepping stones for birds (Table 1). Additional habitat features may be needed to assist other organisms to move through the matrix. For example, decaying logs and half-buried rocks were used by several species of reptiles that used both the matrix and patches (Table 2). It is possible that without these 
features in the matrix, currently continuous populations of some reptile species may become isolated. Importantly, the permeability of the matrix (sensu Gascon and Lovejoy 1998) can depend on different habitat features for different species. Hence, the creation or conservation of a heterogeneous matrix can benefit a range of species.

Landscape context and heterogeneity also have been found to be important in other parts of the world (e.g., McGarigal and McComb 1995; Villard et al. 1999; Hamer et al. 2003). The role of the matrix as a connecting landscape element has been noted in various studies, for example, for many vertebrates in the Amazon basin (Gascon et al. 1999; Laurance 2002), the Iberian Lynx (Lynx pardinus) in Spain (Ferreras 2001), or small mammals in an agricultural area of central-west Indiana (Nupp and Swihart 2000). While several authors have pointed out speciesspecific differences in their ability to tolerate the matrix (e.g., Laurance 1994; Nupp and Swihart 2000), a soft matrix can often be a starting point to enhance connectivity for organisms whose populations in different patches are otherwise isolated (Rosenberg et al. 1997).

\section{A soft matrix can link multiple habitats for a given species}

Not all species are restricted to one habitat type throughout their life history. The most striking example of this phenomenon is semi-aquatic organisms, which typically breed in wet environments, but spend other parts of their life cycle in drier environments. At Nanangroe, outside its breeding season, the Eastern Banjo Frog (Limnodynastes dumerillii) was pitfall-trapped in locations several hundred metres away from the nearest potential breeding environment (Fischer et al., unpublished data). Work in northern Europe also demonstrates that a soft matrix can be crucial to enable semi-aquatic species to move between breeding and non-breeding environments. For example, the Common Toad (Bufo bufo) may move more than $2 \mathrm{~km}$ every year between its aquatic breeding environment and summer or winter habitats respectively (Blab and Vogel 1996). The nature of the matrix encountered by individual toads during these migrations is crucially important to their survival - for example, deaths from road traffic are a substantial source of mortality in northern European amphibians (Blab and Vogel 1996; Hels and Buchwald 2001). A similar situation was reported for threatened turtle species in Maine (USA). Joyal et al. (2001) found that turtles were using multiple small wetlands, and throughout the year frequently moved several hundred metres between wetlands through the landscape matrix. This finding led the authors to conclude that wetland protection by itself was insufficient to ensure the survival of turtle populations, and matrix management was a critical component of the protection of turtle habitat. Despite the special situation of semi-aquatic organisms, animals that do not undergo major biological changes throughout their life history can also undergo changes in habitat use depending on their age (e.g., pre- and postdispersal habitat; see Palomares et al. (2000) for an example of the Iberian Lynx in Spain). 


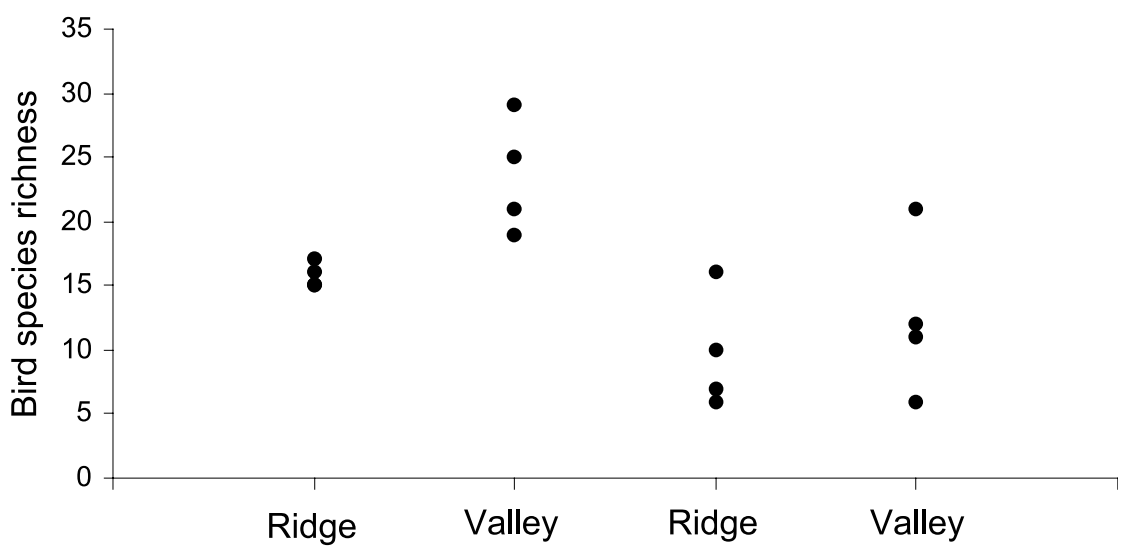

Above average canopy cover Below average canopy cover

Figure 1. Results of bird surveys conducted at 16 landscape units in the Nanangroe area in 2001/2002 (Fischer et al., unpublished data - see text for details). The data illustrate that bird species richness tended to be higher in more productive valley environments than on ridge tops.

The matrix samples the most productive parts of the environment

Human landscape modification is not a random process (Burgman and Lindenmayer 1998). Humans choose areas for production on the basis of accessibility and productivity. This bias means that many nature reserves are in steep and unproductive terrain unsuitable for other purposes (Margules and Pressey 2000; Paton 2000). Similarly, in production landscapes, most remnant vegetation occurs on the less productive hilltops (Lemckert 1998; Gibbons and Boak 2002). Given this bias, the matrix can be an important area for conservation management, because it has the potential to support different elements of biodiversity than less productive areas. Our most recent field survey of birds in Nanangroe illustrated this finding. During our reptile surveys in 2001/2002 we also surveyed 16 landscape units for birds. Each landscape unit measured approximately 2.5 ha, and landscape units were stratified on the basis of their topographic position (valley or ridge) and relative canopy cover (high or low). Repeat bird surveys were conducted for 10 days at each landscape unit when pitfall traps were visited. The results of our bird surveys illustrated that productive valley environments with above average tree cover supported a higher number of bird species than less productive ridge tops with similar levels of tree cover (Figure 1). Similarly, although more data would be needed for conclusive evidence, valley environments with below average tree cover tended to support more bird species than ridge environments with below average tree cover (Figure 1). These considerations highlight the potential value of restoring parts of the landscape matrix because it often coincides with the most productive parts of the landscape, and thus can provide ecological benefits that less productive environments cannot offer. 


\section{Current conservation practices and the future of the matrix}

A soft matrix can provide habitat and facilitate connectivity, and will often sample the most productive parts of the environment. However, most conservation strategies in the grazing landscapes of south-eastern Australia do not target the matrix, but focus solely on patches of remnant woodland. The two most widespread conservation activities are (1) fencing off selected woodland areas from grazing, and (2) tree planting in fenced off areas (Bennett et al. 2000). These practices are a useful starting point, since they aim to ensure that some habitat can recover from grazing pressure, and create new habitat in other places. However, we are concerned that while these activities take place, much habitat and ecological continuity will be lost because of continuing and severe degradation of the landscape matrix.

In many grazing landscapes of southeastern Australia, the neglect of the matrix will lead to a lack of tree regeneration due to grazing pressure. For example, large parts of the Nanangroe landscape are characterised by an almost complete lack of natural tree regeneration. In 144 of $10 \mathrm{~m} \times 10 \mathrm{~m}$, plots established for pitfall trapping, 94 trees were measured, and there were no trees shorter than $150 \mathrm{~cm}$, and only two trees with a diameter at breast height of less than $5 \mathrm{~cm}$. A similar finding was made by Spooner et al. (2002) in a more extensive investigation of tree regeneration in the south-west slopes of south-eastern Australia. These workers found no tree regeneration in $87 \%$ of unfenced woodland remnants. A recent study by Saunders et al. (2003) demonstrated that the threat of a rapid future loss of tree cover was equally pertinent in Western Australia. Repeat surveys of all individual trees in a 15 ha grazed woodland remnant showed a significant decline in tree condition between 1978 and 1998. In addition, Saunders et al. (2003) noted there had been no tree regeneration throughout the entire remnant since grazing commenced in 1929. In the absence of tree regeneration in the wheat-sheep regions of Australia, there will be a severe decrease in tree-associated habitat features in the areas between fenced off patches. A lack of tree regeneration will lead to a deterioration in matrix heterogeneity, and may mark the transition of currently variegated landscapes into fragmented or relictual landscapes (sensu McIntyre and Hobbs 1999).

\section{Barriers to matrix management}

Despite repeated calls for more integrated landscape management in production landscapes (e.g., Noss 1983; Hobbs et al. 1993; Barrett et al. 1994; Morton et al. 1995), on-ground changes have been few in the grazing landscapes of south-eastern Australia. Achieving fundamental changes is not straightforward there are important socio-economic, historical, policy, and legal constraints that need to be overcome to achieve more sympathetic matrix management in the future. 
Land managers have tangible economic reasons to be interested in the short-term output of produce from their land. Conservation considerations are a relatively recent concern to these stakeholders - for example, in Australia, the clearing and 'improvement' of land was for many years rewarded by the government through tax incentives (Saunders 1994; State of the Environment Advisory Council 1996).

The allocation of land for production or conservation respectively (rather than landscape scale matrix management) is currently the most popular way of conservation management since it requires no fundamental changes to land management practices (Lindenmayer and Franklin 2002). For example, fencing off certain patches to be 'sacrificed' for conservation is costly in terms of the funds required for labour and materials (Fenton 1997), but these measures can be implemented without fundamental changes to land management elsewhere on the property. This natural tendency towards solving conservation issues through land allocation strategies is enhanced by the fact that clearing has been biased in the past - that is, the most productive areas are often already cleared (Lemckert 1998; Gibbons and Boak 2002), and the largest patches of semi-natural vegetation are often located in areas that are relatively unsuitable for production anyway. Thus, excluding these areas from production is a sacrifice that may be costly in terms of materials and labour, but can be integrated relatively easily with existing farming practices. Further, Bennett et al. (2000) showed that most revegetation activities on Australian farms aimed to establish linear strips of vegetation, which could be easily integrated with current paddock boundaries and were easiest to work around during farming operations (e.g., cropping). Indeed, Bennett et al. (2000) found that the primary reason for revegetation activities was to enhance production, not to aid biodiversity conservation.

Unlike fencing off patches or establishing linear plantings, sympathetic matrix management may be more difficult to reconcile with many existing management strategies because it requires heterogeneity across the entire landscape - for example, it may involve changes to stocking/cropping regimes, or the establishment of additional temporary or permanent fences, and coordination of multiple landholders. Thus, while there is considerable momentum in the farming community to work towards sustainable management practices with respect to nature conservation (e.g., Davidson 1995; King 1995; Milne 1995; Fenton 1997), there are short-term economic and historical barriers that work against changes to matrix management. Future research in this area is critical to establish ways to manage entire landscapes more sustainably. What exactly are the economic barriers to more sustainable matrix management? What are the short- and long-term costs and benefits from various different conservation and production activities? Do ecologically diverse systems provide a larger amount of ecosystem goods and services (Daily 1999, 2001)? The answers to these and related questions may provide useful ways forward because they may highlight economic incentives to sustainably manage agricultural land that have been overlooked to date. 


\section{Legal constraints}

The ecologically undesirable paradigm of land use allocation to address issues of biodiversity conservation is also apparent in current environmental legislation. The disregard for the matrix in existing legislation most likely arises from a degree of ignorance about its importance, and political pressure to avoid conservation measures that are unpopular. Australia's land clearing rate is still among the highest in the world, partly because of high clearing rates in the state of Queensland (Glanznig 1995; Glanznig and Kennedy 2000). Nevertheless, other states also continue to clear land, and current environmental legislation highlights the disregard for the potential value of remnant vegetation scattered throughout the landscape matrix.

The New South Wales Native Vegetation Conservation Act 1997 aims to provide for the management of native vegetation in accordance with the principles of ecologically sustainable development. While it generally prohibits the clearing of native vegetation without development consent, it contains several exemptions which allow clearing of native vegetation. Current practices falling under these exemptions include the clearing of up to 2 ha of native vegetation every year on an individual property. Similarly, seven trees per hectare may be removed in any given year for on farm purposes. Finally, all tree regeneration in the matrix that is younger than 10 years of age may be cleared (Department of Land and Water Conservation 1999; Sundstrom 2001; Bates 2002). These exemptions demonstrate which aspects of native vegetation are considered worthwhile conserving - small patches and recently regenerated trees in the matrix are essentially deemed worthless for nature conservation. Hence, the current legal framework in New South Wales contrasts starkly with the actual ecological importance of small patches and scattered trees in the landscape matrix. Similarly, the legal frameworks for native vegetation conservation in other Australian jurisdictions contain a wide range of exemptions that are rarely grounded in ecological reality (Bates 2002).

In addition to deficiencies in legislation to adequately account for the value of the matrix, a lack of sufficient law enforcement may render existing provisions uneffective. For example, in New South Wales, there is some concern that the number of cases where illegal clearing has been successfully prosecuted is negligible (Department of Infrastructure, Planning and Natural Resources, unpublished information). Thus, there is at least some suggestion that for legislation to be effective, prosecution may need to be more rigorous.

\section{Scientific constraints}

Economic, historical and legal constraints to more sympathetic matrix management can be further enhanced through the uncritical adoption of existing scientific paradigms. For example, the theory of island biogeography (MacArthur and Wilson 1967) was an important foundation of conservation biology (Diamond 1975; reviewed by Haila 2002). The resulting concept of patchy landscapes easily lent itself to a binomial classification of land into habitat and non-habitat (Lindenmayer et al. 
2003), and thus was consistent with a conservation approach based on land use allocation. In addition, traditional scientific thinking is strongly based on hypothetico-deductive investigations, and therefore most scientists are likely to feel most comfortable dealing with clearly defined categories as provided by theoretical tools such as the patch-matrix model (Wiens 1995). However, while a binomial classification of land may be useful in some landscapes, more integrated management considering entire landscapes will be important in many cases.

An additional reason why scientists have been reluctant to act in accordance with calls for more integrated landscape management, may be the perceived political reality they find themselves in. Given a certain political climate, conciliatory approaches with land managers that do not require fundamental changes to land management sometimes appear more likely to be worthwhile than approaches that are more challenging to the land manager and advocate more fundamental changes. However, while a sense of realism with respect to the political climate is important, only ecologists will have the necessary information and a firm basis from which to argue for more sympathetic matrix management - indeed, economic and historical realities that may be of primary relevance to other stakeholders will not allow changes to matrix management unless ecologists clearly state well-founded reasons for an abandonment of the status quo and argue strongly for changes to matrix management.

\section{Ways forward}

For conservation biologists to be effective in bringing about changes to matrix management in Australian grazing landscapes, more scientific research is necessary, but this alone is not sufficient. Three additional factors complementing scientific work may be of key importance: (1) an improved understanding of the current policy framework, and the opportunities it provides for change, (2) improved communication with all stakeholders involved, and (3) more practical onground research that highlights potential avenues for more sustainable management practices.

\section{Opportunities for change: understanding the legal framework}

While the clearing exemptions in New South Wales highlight the current neglect of the matrix, a more detailed examination of the legal framework highlights several potential avenues through which change may be achieved. First, the exemptions under the Native Vegetation Conservation Act 1997 are transitional provisions remaining from earlier legislation (State Environmental Planning Policy No. 46: Protection and Management of Native Vegetation). These exemptions may be removed or altered by either Regional Vegetation Management Plans or Native Vegetation Codes of Practice (Bates 2002). The Nanangroe area falls under one of two Regional Vegetation Management Plans that have already been gazetted, the 
Riverina Highlands Regional Vegetation Management Plan 2003. While this Plan modifies the exemptions discussed above to some extent, subject to some conditions, it still allows for the annual removal of up to 10 trees per hectare and all regrowth younger than 10 years of age. Hence, the changes brought about in this case were somewhat insignificant with respect to their effect on matrix management. However, there are 19 Regional Vegetation Management Plans at various stages of development, to which input can still be made. Communicating the important role of a soft matrix to the relevant Regional Vegetation Committees may be a possible avenue to improve the legal protections accorded to the matrix. Indeed, provision of robust scientific data to these Committees is essential to assist them to adequately discharge their responsibilities (Thompson 2001).

Second, the Native Vegetation Conservation Act 1997 also contains provision for property agreements. These are voluntary but enforceable agreements made between landholders and the Department of Infrastructure, Planning and Natural Resources, which include the development of a strategy for native vegetation management on individual or multiple properties, in conjunction with the provision of technical and financial assistance to the landholder (Department of Land and Water Conservation 1998; Ferrier et al. 1999). Again, communicating the importance of a soft matrix to the NSW Department of Infrastructure, Planning and Natural Resources, which administers these property agreements, and the farming community could result in the inclusion of more integrated matrix management into native vegetation management strategies. The advantage of this second example is that it also addresses to some extent the economic implications of a shift towards sympathetic matrix management.

While understanding the policy framework that governs matrix management can be useful to identify avenues for improvement, it is important to realise that achieving changes in environmental policy is not a straightforward task. There is a clear need for more interdisciplinary work examining the links between science, policy development and institutional structures to improve the implementation of scientific findings into policy frameworks (Ison and Russell 2000; Lindenmayer and Franklin 2002).

\section{Communicating complexity and urgency}

To achieve changes in matrix management, scientists will have to communicate with other scientists, government agencies and land managers. It will be important to explicitly distinguish between different audiences that scientists want to reach. The potentially important role of habitat features that do not coincide with large patches of remnant woodland needs to be communicated widely to land managers it will be important to emphasise that habitat is more than trees, and that a soft matrix can provide habitat for a range of animals. However, confronting individual farmers and 'demanding' they implement integrated matrix management is bound to fail and is unrealistic given the economic realities with which individual farmers have to deal. Indeed, Fischer and Lindenmayer (2002a) argued that it was important 
to realise that even small conservation efforts could be worthwhile, and should be encouraged. Conversely, the true complexity of ecological systems including the role of the matrix will need to be communicated to other scientists, to the farming community as a whole, and to politicians and policy makers. Sustainability as a goal of environmental management has become a popular catch phrase, but it is important to recognise that different levels of diversity may be conserved as a result of different conservation approaches. In the grazing landscapes of southeastern Australia, an approach of land use allocation will lead to 'patchy' landscapes, which may look somewhat reminiscent of northern Europe. On the other hand, a more integrated approach may lead to the conservation of different types of landscapes representing a range of different alteration states (see McIntyre and Hobbs 1999). Both approaches may eventually lead to a stable level of biodiversity, but the absolute amount of diversity supported is likely to be substantially higher if a more integrated approach to land management is employed that considers not only patches, but also the matrix. Given these considerations, it is by no means clear that ecological researchers are doing better, that is, conserving more biological diversity, by following a non-confrontational pragmatic approach to conservation through land use allocation. Indeed, in the context of the global reserve network, it is recognised that a global target of setting aside $10 \%$ of all land for conservation is likely to be vastly insufficient (Rodrigues and Gaston 2001).

\section{The need for practical research}

New research methods that complement reductionist approaches may be helpful to derive effective management tools. An increased use of systems dynamics approaches may be a useful starting point to assist us to better conceptualise complex environmental systems (Senge 2001), and may help integrate the knowledge and perspectives of a wide range of disciplines (Jackson et al. 2001). Multidisciplinary investigations will be necessary to consider the range of ecological, economic and social issues associated with changes in matrix management. At an applied level, future projects may include investigations into various grazing regimes and their effect on matrix condition, and the identification or establishment of 'model farms' that are managed sustainably.

\section{Conclusions}

Our case study illustrated that the concept of patches is deeply embedded in conservation strategies used in Australian grazing landscapes, and the role of the matrix is largely ignored. This finding highlights the potential negative effects that can arise from over- or misapplying ecological theories (see also Haila 2002). While much of our case study focused directly on New South Wales, the problem of undervaluing the matrix is not unique to Australia. For example, research in the USA suggests that small wetlands may be undervalued in a similar way to small 
woodland patches in Australia (Semlitsch and Bodie 1998; Joyal et al. 2001). Addressing conservation issues in the matrix will require a sound scientific understanding of the matrix. However, insights from non-scientific disciplines also will be important.

\section{Acknowledgements}

We are grateful for discussions on this topic with a range of colleagues, including A. Manning, H. Nix, G. Sanecki and A. Wayne. S. Dovers and an anonymous referee provided helpful comments on earlier versions of this manuscript.

\section{References}

Antrop M. 2001. The language of landscape ecologists and planners - a comparative content analysis of concepts used in landscape ecology. Landscape and Urban Planning 55: 163-173.

Barrett G.W., Ford H.A. and Recher H.F. 1994. Conservation of woodland birds in a fragmented rural landscape. Pacific Conservation Biology 1: 245-256.

Bates G. 2002. Environmental Law in Australia. Reed International Books, London.

Beier P. and Noss R.F. 1998. Do habitat corridors provide connectivity? Conservation Biology 12: 1241-1252.

Bennett A.F. 1998. Linkages in the Landscape: The Role of Corridors and Connectivity in Wildlife Conservation. IUCN, Gland, Switzerland.

Bennett A.F., Kimber S. and Ryan P. 2000. Revegetation and Wildlife. Research Report 2/00. Bushcare National Projects Research and Development Program. Environment Australia, Canberra, Australia.

Blab J. and Vogel H. 1996. Amphibien und Reptilien erkennen und schuetzen: Alle mitteleuropaeischen Arten. BLV Verlagsgesellschaft, Munich, Germany.

Burgman M.A. and Lindenmayer D.B. 1998. Conservation Biology for the Australian Environment. Surrey Beatty \& Sons, Chipping Norton, New South Wales, Australia.

Cunningham R.B., Lindenmayer D.B., Nix H.A. and Lindenmayer B.D. 1999. Quantifying observer heterogeneity in bird counts. Australian Journal of Ecology 24: 270-277.

Daily G.C. 1999. Developing a scientific basis for managing Earth's life support systems. Conservation Ecology 3: 14. [online] URL: http://www.consecol.org/vol13/iss12/art14.

Daily G.C. 2001. Ecological forecasts. Nature 411: 245.

Davidson R.L. 1995. Farmers as conservators of a sustainable production base. In: Bradstock R.A., Auld T.D., Keith D.A., Kingsford R.T., Lunney D. and Sivertsen D.P. (eds) Conserving Biodiversity: Threats and Solutions. Surrey Beatty and Sons, Chipping Norton, New South Wales, Australia, pp. 43-54.

Department of Land and Water Conservation 1998. Native Vegetation Conservation Act Factsheet No. 4: Property Agreements. NSW Department of Land and Water Conservation, Sydney, Australia.

Department of Land and Water Conservation 1999. Guidelines for clearing vegetation under the Native Vegetation Conservation Act 1997. NSW Department of Land and Water Conservation, Parramatta, Australia.

Diamond J.M. 1975. The island dilemma: lessons of modern biogeographic studies for the design of natural reserves. Biological Conservation 7: 129-145.

Fenton J. 1997. A primary producer's perspective on nature conservation. In: Hale P. and Lamb D. (eds) Conservation Outside Nature Reserves. University of Queensland, Brisbane, Australia, pp. 3-9.

Fernández-Juricic E. 2000. Avifaunal use of wooded streets in an urban landscape. Conservation Biology 14: 513-521.

Ferrier D., Lyster R., Pearson L. and Lipman Z. 1999. The Environmental Law Handbook. Redfern Legal Publishing, Sydney, Australia. 
Fischer J. and Lindenmayer D.B. 2002a. Small patches can be valuable for biodiversity conservation: two case studies on birds in southeastern Australia. Biological Conservation 106: 129-136.

Fischer J. and Lindenmayer D.B. 2002b. The conservation value of paddock trees for birds in a variegated landscape in southern New South Wales. 1. Species composition and site occupancy patterns. Biodiversity and Conservation 11: 807-832.

Fischer J. and Lindenmayer D.B. 2002c. The conservation value of paddock trees for birds in a variegated landscape in southern New South Wales. 2. Paddock trees as stepping stones. Biodiversity and Conservation 11: 833-849.

Franklin J.F. 1993. Preserving biodiversity: species, ecosystems, or landscapes? Ecological Applications 3: 202-205.

Gascon C. and Lovejoy T.E. 1998. Ecological impacts of forest fragmentation in central Amazonia. Ecology 101: 273-280.

Gascon C., Lovejoy T.E., Bierregaard R.O.J., Malcolm J.R., Stouffer P.C., Vasconcelos H.L. et al. 1999. Matrix habitat and species richness in tropical forest remnants. Biological Conservation 91: 223-229.

Gibbons P. and Boak M. 2002. The value of paddock trees for regional conservation in an agricultural landscape. Ecological Management and Restoration 3: 205-210.

Glanznig A. 1995. Native vegetation clearance, habitat loss and biodiversity decline. Department of the Environment, Sport and Territories, Canberra, Australia.

Glanznig A. and Kennedy M. 2000. From words to action: addressing biodiversity loss, land degradation and native vegetation clearance in the 1990s - the Australian experience. http://www.nccnsw.org. $\mathrm{au} / \mathrm{member} / \mathrm{cbn} /$ projects/Policy_and_Law/vegman.html, visited April 2001.

Grant B.W., Tucker A.D., Lovich J.E., Mills A.M., Dixon P.M. and Gibbons J.W. 1991. The use of coverboards in estimating patterns of reptile and amphibians biodiversity. In: McCullough D.R. and Barrett R.H. (eds) Wildlife 2001: Populations. Elsevier Applied Science, London, pp. 379-403.

Haila Y. 2002. A conceptual genealogy of fragmentation research: from island biogeography to landscape ecology. Ecological Applications 12: 321-334.

Hamer K.C., Hill J.K., Benedick S., Mustaffa N., Sherratt T.N., Maryati M. et al. 2003. Ecology of butterflies in natural and selectively logged forests of northern Borneo: the importance of habitat heterogeneity. Journal of Applied Ecology 40: 150-162.

Hels T. and Buchwald E. 2001. The effect of road kills on amphibian populations. Biological Conservation 99: 331-340.

Higgs A.J. and Usher M.B. 1980. Should nature reserves be large or small? Nature 285: 568-569.

Hobbs R.J., Saunders D.A. and Arnold G.W. 1993. Integrated landscape ecology: a Western Australian perspective. Biological Conservation 64: 231-238.

Horner-Devine M.C., Daily G.C., Ehrlich P.R. and Boggs C.L. 2003. Countryside biogeography of tropical butterflies. Conservation Biology 17: 168-177.

Hughes J.B., Daily G.C. and Ehrlich P.R. 2002. Conservation of tropical forest birds in countryside habitats. Ecology Letters 5: 121-129.

Ison R.L. and Russell D.B. (eds) 2000. Agricultural Extension and Rural Development: Breaking Out of Traditions. Cambridge University Press, Cambridge, UK.

Jackson J.B.C., Kirby M.X., Berger W.H., Bjorndal K.A., Botsford L.W., Bourque B.J. et al. 2001. Historical overfishing and the recent collapse of coastal ecosystems. Science 293: 629-638.

Joyal L.A., McCollough M. and Hunter M.L. 2001. Landscape ecology approaches to wetland species conservation: a case study of two turtle species in southern Maine. Conservation Biology 15: 1755-1762.

King G. 1995. The contribution of farm organizations to wildlife conservation and management of private land. In: Bennett A., Backhouse G. and Clark T. (eds) People and Nature Conservation. Surrey Beatty and Sons, Chipping Norton, New South Wales, Australia, pp. 201-203.

Kitchener D.J. 1982. Predictors of vertebrate species richness in nature reserves in the Western Australian Wheatbelt. Australian Wildlife Research 9: 1-7.

Laurance W.F. 1991. Ecological correlates of extinction proneness in Australian tropical rain forest mammals. Conservation Biology 5: 79-89.

Laurance W.F. 1994. Rainforest fragmentation and the structure of small mammal communities in tropical Queensland. Biological Conservation 69: 23-32. 
Laurance W.F., Lovejoy T.E., Vasconcelos H.L., Bruna E.M., Didham R.K., Stouffer P.C. et al. 2002. Ecosystem decay of Amazonian forest fragments: a 22-year investigation. Conservation Biology 16: 605-618.

Lemckert F. 1998. A survey for threatened herpetofauna of the south-west slopes of New South Wales. Australian Zoologist 30: 492-500.

Lindenmayer D.B. 1994. Wildlife corridor mitigation of logging impacts on fauna in wood-production forests in south-eastern Australia: a review. Wildlife Research 21: 323-340.

Lindenmayer D.B. 1998. The design of wildlife corridors in wood production forests. NSW National Parks and Wildlife Service, Hurstville, New South Wales, Australia.

Lindenmayer D.B. and Franklin J. 2002. Conserving Forest Biodiversity. Island Press, Covelo, Australia.

Lindenmayer D.B., Cunningham R.B., MacGregor C., Tribolet C. and Donnelly C.F. 2001. A prospective longitudinal study of landscape matrix effects on fauna in woodland remnants. I. Experimental design and baseline data. Biological Conservation 101: 157-169.

Lindenmayer D.B., McIntyre S. and Fischer J. 2003. Birds in eucalypt and pine forests: landscape alteration and its implications for research models of faunal habitat use. Biological Conservation 110: $45-53$.

Luck G.W. and Daily G.C. 2003. Tropical countryside bird assemblages: richness, composition, and foraging differ by landscape context. Ecological Applications 13: 235-247.

Lumsden L.F., Bennett A.F. and Silins J.E. 2002. Location of roosts of the lesser long-eared bat $\mathrm{Nyc}$ tophilus geoffroyi and Gould's wattled bat Chalinolobus gouldii in a fragmented landscape in southeastern Australia. Biological Conservation 106: 237-249.

MacArthur R.H. and Wilson E.O. 1967. The Theory of Island Biogeography. Princeton University Press, Princeton, New Jersey.

Margules C.R. and Pressey R.L. 2000. Systematic conservation planning. Nature 405: 243-253.

McGarigal K. and McComb W.C. 1995. Relationships between landscape structure and breeding birds in the Oregon coast range. Ecological Monographs 65: 235-260.

McIntyre S. and Barrett G.W. 1992. Habitat variegation, an alternative to fragmentation. Conservation Biology 6: 146-147.

McIntyre S. and Hobbs R. 1999. A framework for conceptualizing human effects on landscapes and its relevance to management and research models. Conservation Biology 13: 1282-1292.

Milne B. 1995. Broadening the basis for enhancing biodiversity - a farmer's perspective. In: Bennett A., Backhouse G. and Clark T. (eds) People and Nature Conservation. Surrey Beatty and Sons, Chipping Norton, New South Wales, Australia, pp. 204-208.

Morton S.R., Stafford Smith D.M., Friedel M.H., Griffin G.F. and Pickup G. 1995. The stewardship of arid Australia: ecology and landscape management. Journal of Environmental Management 43: 195-217.

Noss R.F. 1983. A regional landscape approach to maintain diversity. Bioscience 33: 700-706.

Nupp T.E. and Swihart R.K. 2000. Landscape-level correlates of small-mammal assemblages in forest fragments of farmland. Journal of Mammalogy 81: 512-526.

Orr D.W. 2002. Four challenges of sustainability. Conservation Biology 16: 1457-1460.

Palomares F., Delibes M., Ferreras P., Fedriani J.M., Calazada J. and Revilla E. 2000. Iberian lynx in a fragmented landscape: predispersal, dispersal, and postdispersal habitats. Conservation Biology 14: 809-818.

Paton D.C. 2000. Disruption of bird-plant pollination systems in southern Australia. Conservation Biology 14: 1232-1234.

Ricketts T.H., Daily G.C., Ehrlich P.R. and Fay J.P. 2001. Countryside biogeography of moths in a fragmented landscape: biodiversity in native and agricultural habitats. Conservation Biology 15: 378-388.

Rodrigues A.S.L. and Gaston K.J. 2001. How large do reserve networks need to be? Ecology Letters 4: 602-609.

Rosenberg D.K., Noon B.R. and Meslow E.C. 1997. Biological corridors: form, function, and efficacy. Bioscience 47: 677-687.

Saunders D.A. 1994. Can we integrate nature conservation with agricultural production? Landscape and Urban Planning 28: 55-62. 
Saunders D.A. and de Rebeira C.P. 1991. Values of corridors to avian populations in a fragmented landscape. In: Saunders D.A. and Hobbs R.J. (eds) Nature Conservation 2: The Role of Corridors. Surrey Beatty and Sons, Chipping Norton, New South Wales, Australia, pp. 221-240.

Saunders D.A., Arnold G.W., Burbidge A.A. and Hopkins A.J.M. (eds) 1987. Nature Conservation: The Role of Remnants of Native Vegetation. Surrey Beatty and Sons, Chipping Norton, New South Wales, Australia.

Saunders D.A., Smith G.T., Ingram J.A. and Forrester R.I. 2003. Changes in a remnant of salmon gum Eucalyptus salmonophloia and York gum E. loxophleba woodland, 1978 to 1997. Implications for woodland conservation in the wheat-sheep regions of Australia. Biological Conservation 110: 245-256.

Semlitsch R.D. and Bodie J.R. 1998. Are small, isolated wetlands expendable? Conservation Biology 12: 1129-1133.

Senge P.M. 2001. The fifth discipline, the art and practice of the learning organisation. Random House Australia, Sydney, Australia.

Simberloff D.A., Farr J.A., Cox J. and Mehlman D.W. 1992. Movement corridors: conservation bargains or poor investments? Conservation Biology 6: 493-504.

Spooner P., Lunt I. and Robinson W. 2002. Is fencing enough? The short-term effects of stock exclusion in remnant grassy woodlands in southern NSW. Ecological Management and Restoration 3: 117-126.

State of the Environment Advisory Council 1996. State of the environment Australia 1996. CSIRO Publishing, Collingwood, Australia.

Stephens D.W. and Krebs J.R. 1986. Foraging Theory. Princeton University Press, Princeton, New Jersey. Sundstrom A. 2001. A licence to clear? An assessment of the effectiveness of clearing control laws in NSW. National Parks Journal 45: 10-11.

Taylor P.D., Fahrig L., Henein K. and Merriam G. 1993. Connectivity is a vital element of landscape structure. Oikos 68: 571-573.

Thompson D. 2001. Flying blind with native vegetation conservation? Australian Farm Journal October: 66-69.

Villard M.-A., Trzcinski M.K. and Merriam G. 1999. Fragmentation effects on forest birds: relative influence of woodland cover and configuration on landscape occupancy. Conservation Biology 13: $774-783$.

Wiens J.A. 1995. Landscape mosaics and ecological theory. In: Hansson L., Fahrig L. and Merriam G. (eds) Mosaic Landscapes and Ecological Processes. Chapman \& Hall, London, pp. 1-26.

Wiens J.A., Stenseth N.C., Vanhorne B. and Ims R.A. 1993. Ecological mechanisms and landscape ecology. Oikos 66: 369-380.

Yates C.J. and Hobbs R.J. 1997. Temperate eucalypt woodlands: a review of their status, processes threatening their persistence and techniques for restoration. Australian Journal of Botany 45: 949-973. 